DOI: https://doi.org/10.15407/techned2019.06.049

\title{
MUNICIPAL SOLID WASTES AS ENERGY RESOURSE
}

Journal

Publisher

ISSN

Issue

Pages
Tekhnichna elektrodynamika

Institute of Electrodynamics National Academy of Science of Ukraine 1607-7970 (print), 2218-1903 (online)

No 6, 2019 (November/December)

$49-58$

\section{Authors}

\section{I.M. Karp, K.Y. Pyanykh}

The Gas Institute of NAS of Ukraine, 39, Dehtiarivska str., Kyiv, 03113, Ukraine, e-mail: karpkiev@gmail.com, pyanykh@gmail.com

\begin{abstract}
Technological aspects of energy use of solid municipal wastes and possibilities of application of some technologies in Ukraine are analyzed. Partial sorting of wastes can use for energy production half of their energy potential that for Ukraine is estimated in an equivalent of natural gas in 1,5 billion m3. The share of food waste is close to $40 \%$. It is advisable to process them into biogas and biomethane in mixtures with agricultural waste and energy plants. The production of electricity and heat from biogas requires the assistance of the states in the form of special tariffs. The use of biomethane, along with natural gas in a compressed and liquefied state in the transport energy sector is becoming widespread. Biogas complexes are used as balancing capacities of power grids. The most common technology for using the energy potential of solid waste is incineration. Waste incineration plant exhaust gas treatment systems have achieved a degree of perfection that allows them to be placed close to residential buildings. References 16, tables 2.
\end{abstract}

Key words: municipal solid wastes, food wastes, biomethane, combustion. 
Received: 24.05.2019

Accepted: 06.07.2019

Published: 25.10.2019

\section{References}

1. Energy Strategy of Ukraine till 2035: Security, Energy Efficiency, Competitiveness. The Order of Cabinet of Ministers dated

. August 18, 2017 № 605-p. (Ukr)

2. National strategy of management wastes till 2030. Order of Cabinet of Ministers of Ukraine from November 8, 2017. № 820-p. (Ukr)

3. Voitsikhovska A. Clear Ukraine: mission (not) feasible? URL: https://dt.ua/ECOLOGY/rozchi stiti-ukrayinu-misiya-ne-zdiysnenna-254196.html

(accessed 16.05.2019). (Ukr)

4. About wastes. A law of Ukraine No 187/98-VR on March, 5, 1998. Release from 04.10.2018.

Lists of Supreme Council of Ukraine. 1998. No 36-37. 242 p. (Ukr)

5. ESWET Responds to Eurostat Findings on Municipal Waste Treatment in EU. Informative sheet of ISWA - international association of hard wastes (International Solid Wastes Accosiation) dated 05.02.2019 p.

6. Zhuk H.V., Nikitin E.E., Smikhula A.V., Dutka O.V., Uvaniv O.S. Determination of optimal scemes of solid wastes management in cities of Ukraine. Energotekhnologii $i$ resursosberezhenie . 2018. No 1. Pp.

48-59. (Ukr) DOI: http

s://doi.org/10.33070/etars.1.2018.07

7. Ukraine Landfill Gas Model. Landfill Methane Outreach Program US Environment Protection Agency Washington DC. 12/2009. 28 p. URL: https:// www.globalmethane.org/documents/toolsres_lfg manual.pdf (accessed 16.05.2019)

8. Information from Company Accord Ltd. URL: https:// www.bio-gas.com.ua/biogas (accessed 08.05.2019)

9. Kyrylenko O.V. Intelligent Electric Networks: Elements and Models. Kyiv: Instytut Elektrodynamiky Natsionalnoi Academii Nauk Ukrainy, 2016. 400 p. (Ukr)

10. Belgiorno V., De Feo G., Della Rocca C. Energy from gasification of solid wastes. Waste Management 23

.2003. Iss. 1. Pp. 1-15.

DOI:

https://doi.org/10.1016/S0956-053X(02)00149-6

11. Clean Investment Firm Full Cycle Backs Waste Gasification Technology. Newsletter. 2018, 11 November. URL: http://waste-management-world.com (accessed 06.05.2019)

12. Uddin M., Techato K., Taweekun J., Rasul M., Mahlia T., Ashrafur S. An Overview of 
Recent Developments in Biomass Pyrolysis Technologies. Energies. 2018. Vol. 11. Iss. 11.3115. 23 p. DOI:

//doi.org/10.3390/en11113115

https:

13. Near-zero emission Bio-CHP Waste-to-Energy is now: Waste-to-Syngas-to-EcoEnergy with D4 Technology Installation (the only Hydro-Pyrolisis WtE Installation in the world). PLUS Development Group Polska. Presentation. 2014. 41 p. URL: http://www.plusdg.com (accessed 16.05.2019)

14. Matveyev Y.B., Geletukha G.G. Perspectives of energy utilization of solid wastes in Ukraine. Analytical note of the Ukrainian Biology Society. 2019. No 22. 47 p. URL: http://www uabio.org/activity/uabio -analytics

(accessed 16.05.2019)

15. Panchenko Yu. Waste treatment plant near home: three mythes about wastes utilization in Sweden. European true. 09.11.2018. (Rus)

16. Technical Overview of the Waste-to-Energy Plant in Brno, Plant for Region with 2 mil. people. 2017. URL: http://www.sako.cz/page/en/607/waste-to-energy/ (accessed 06.05.2019) 